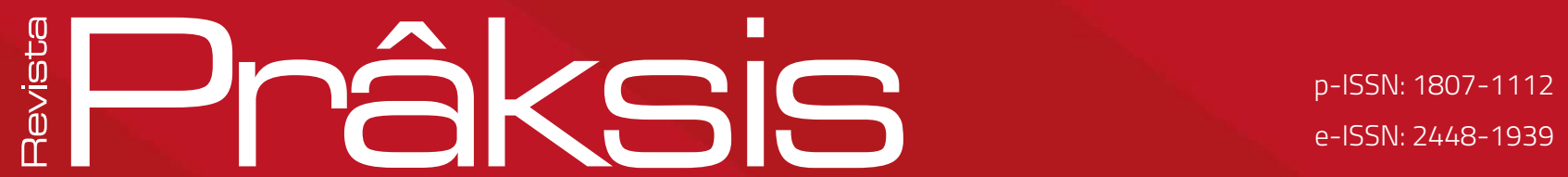

Recebido em: 08 de março de 2019

Aprovado em: 17 de julho de 2019

Sistema de Avaliação: Double Blind Review RPR |a. $16 \mid$ |n. 3 |p. 80-97| set./dez. 2019

DOI: https://doi.org/10.25112/rpr.v3i0.1996

\title{
BEYOND RESEARCH COOPERATION ON SUCCESSFUL AGING: COMPARATIVE ANALYSIS OF THE COGNITIVE PERFORMANCE OF ELDERLY PEOPLE IN BRAZIL AND FINLAND
}

COOPERAÇÃO EM PESQUISA SOBRE O ENVELHECIMENTO BEM SUCEDIDO: ANÁLISE DE COMPARAÇÃO DO DESEMPENHO COGNTIVO DE PESSOAS IDOSAS NO BRASIL E NA FINLÂNDIA

\section{Geraldine Alves dos Santos}

Psychologist. PhD in psychology. Professor at Feevale University. Postgraduate Program in Cultural Diversity and Social Inclusion. E-mail: geraldinesantos@feevale.br

\section{Päivi Sanerma}

Nurse. PhD. Senior Lecturer. HAMK University. E-mail: paivi.sanerma@hamk.fi 


\section{ABSTRACT}

Many studies have been carried out, mainly in the last decades, to understand the normal and pathological process of aging in the different areas of knowledge. However, many gaps still remain in the progress of science. In this sense, the overall objective of the present study was to evaluate the comparison between the performance of congruent elderly people in Brazil and Finland. The study method had a quantitative, descriptive cross - sectional design. The sample consisted of 194 subjects of both sexes, aged between 60 and 79 years, residing in the municipality of Ivoti / Rio Grande do Sul / Brazil and 93 subjects, both genders aged 65 to 85 years residing in Riihimäki / Finland. The instrument used was the Mini Mental State Examination (MMSE). Data were analyzed statistically in SPSS version 25.0 through descriptive analysis of frequency and comparison of means by the Mann Whitney test $(p \leq 0.05)$. The results showed that the cognitive performance of elderly people in the Ivoti group was significantly higher than those of Riihimäki. It can be concluded that cultural variables influenced outcomes, such as experiences in the early stages of human development and current interpersonal relationships.

Keywords: Cognitive performance. Successful aging. Elderly.

\section{RESUMO}

Muitos estudos têm sido realizados, principalmente nas últimas décadas, para compreender o processo normal e patológico de envelhecimento, nas diferentes áreas do conhecimento. Entretanto, muitas lacunas ainda se mantêm presentes no progresso da ciência. Neste sentido, o objetivo geral do presente estudo foi avaliar a comparação entre o desemepnho congitivo de pessoas idosas residentes no Brasil e na Finlândia. $O$ método do estudo teve um delineamento quantitativo, descritivo e transversal. A amostra compreendeu 194 sujeitos, de ambos os sexos, com idade entre 60 e 79 anos, residentes no município de Ivoti/Rio Grande do Sul/Brasil e 93 sujeitos, de ambos os sexos com idade entre 65 e 85 anos residentes em Riihimäki/Finlândia. 0 instrumento utilizado foi o Mini Exame do Estado Mental (MEEM). Os dados foram analisados estatisticamente no programa SPSS versão 25.0 através de análises descritivas de frequência e de comparação de médias pelo teste Mann Whitney $(p \leq 0,05)$. Os resultados demonstraram que o desempenho cognitivo das pessoas idosas do grupo de Ivoti foi significativamente maior que os de Riihimäki. Pode-se concluir que variáveis culturais influenciaram os resultados, tais como experiências nas fases iniciais do desenvolvimento humano e as relações interpessoais atuais.

Palavras-chave: Desempenho cognitivo. Velhice. Idosos. 


\section{INTRODUCTION}

The number of people who reach old age remained reduced until the nineteenth century, when the development of areas such as health and education began, which led to an increase in the life expectancy of the population. During the history of mankind the proportion of the elderly number compared to the number of young people has always been considerably lower due to the hard conditions of survival. The average life expectancy, up to the last century, never remained much above the age of thirty; this significantly differentiates the concept of aging that we currently have.

The aging process is a natural phenomenon of the human species, however the human being is showing the tendency to increase the average life expectancy. Longevity, in this sense, is becoming a phenomenon that causes many discussions and speculations about its social, economic, biological and emotional features. But the increase in life expectancy does not occur uniformly in the world, with certain regions with high average expectations, others with a high expectation, and still others with a good quality of life in the surplus years of existence, which are now considered as successful aging. So, the most important thing for human, exact and biological sciences, is to discover how a person can live up to the maximum limit of his life, which is approximately between 115 and 120 years old, without diseases and, above all, how he can actively living those years within our society.

When we study aging, it is relevant to observe the distinction that Hayflick (2007) proposes between old age and illness. The definition of aging is not synonymous for disease, although they may be associated. At any stage of life the human being is susceptible to the most diverse types of diseases, otherwise there would not be so many problems related to infant mortality. During aging, human immune system decreases the ability to defend the body and therefore the individual becomes more vulnerable to disease, but does not necessarily get sick. There are, according, Hayflick (2007) normal changes of aging such as white hair, hearing loss, wrinkled skin, etc. The author emphasizes that people do not die as a result of these typical changes of aging.

Birren and Birren (1990) argue that initially the development theories related to the aging process comprise the occurrence of changes as a function of biological theories that emphasize the force of natural selection. In this way, the life cycle would be governed by an evolution in the first phase of life and a degeneration in the second phase, which would intensify in all aspects until the occurrence of death. Research indicates that some parts of the body suffer various losses from aging, while others undergo an inverse process in which they become more efficient and reach a greater degree of organization. Currently, the field of research on aging psychology has not been able to reach a degree of complexity that encompasses all the concepts pertinent to a phase of life that, like childhood, can not be based on 
popular concepts and random observations, and there is a need for advances in theories and researches with methodological rigor.

The reality is that we still have to search for elements that remain obscure in the aging process, since it is permeated by many variables such as genetics, environment, socioeconomic level, family, personality, diet, a series of others that are being studied in different nuclei of studies of the area of gerontology. This information, when brought together through interdisciplinary studies, will allow us to elaborate research methods that answer the questions that man has been asking for centuries regarding to well-being in advanced ages and, consequently, to increase the life expectancy, as long as it is healthy and enjoyable.

Living a lot and reaching old age with all the disposition to continue with the activities developed previously are aspects that have disrupted politicians, economists and even shaken the dynamics of the families that still do not know how to deal with the older members. Among the various difficulties found by modern society in relation to the new generation of the elderly, there is the question of retirement, social status and sexuality that are associated with several others, forming a network of stereotypes that prevent people from living this stage of their lives.

Each society observes the aging according to the adopted culture, being able to exist the notion of respect or contempt. Nowadays, the concept and the experience of aging are undergoing a process of restructuring. The new way of defining human old age and the research carried out within the theory of development are gradually being constructed. They are being associated with cultural issues that directly influence biological, social, and health variables, although many questions remain and few significant conclusions have been found. Old age, according to Moragas (2010), is the result of the natural aging process. There are many ways to define aging and also how to measure it.

According to Robine (2019) the elements that promote the adult longevity revolution are directly related to improvements in living conditions such as food, hygiene and safety. In this sense, the author emphasizes the relevance of food, which would be responsible for greater resistance to diseases in general, ie, the quality of food would enable people to be less exposed to health risks, leading to increased longevity. From this perspective, promoting the education of healthy lifestyles is more relevant to successful aging than advances in medicine.

In Finland one important goal in elderly care is that they live at home as long as possible. Municipalities are responsible for offering elderly health and social services. Provision of services is based on evaluation of service needs, Municipalities are offering many kinds of services for elderly living at home. Older people enjoy living at home. Possibility to make decisions on own care is a prerequisite for well-being in home care. Health services have to be available equally for all elderly people in the country (BOEKXTAENS; GRAAF, 2011, KEHUSMAA; VAINIO; ALASTALO, 2016). 
Digital services make it possible to increase elderly citizen's sense of safety. Elderly people like to live at home as long as possible and as long as they feel safe. Better than before, nowadays elderly persons can participate in the decision of making their own services and care. Even in case of memory sickness, an old person should participate in his/her own treatment (KEHUSMAA et al., 2016)

In European countries an important goal of elderly person's services is well-organized primary health care. It includes high quality services and support for active aging (COMISSÃO EUROPÉIA, 2017). The Goal in Europe is to include supportive services and health promotion activities in primary health care of old persons. All citizens have right to get support for independent and active life in old age (CHAPMAN; KEATING; EALES, 2003; BOEKXTAENS; GRAAF, 2011). Participation in one's care is a significant part of the quality of care. The progression of memory disease also increases the feeling of insecurity (KEHUSMAA et al., 2016) Finland has developed an effective home health system for the elderly. Home health services help the elderly live at home independently. Interprofessional teams are necessary for the implementation of home health services in the elderly (THUME et al., 2011). The teams include nurses, nurse assistants, physicians, social workers and physiotherapists. In Finland, home care services are implemented in the digital work and planning environment (TURJAMAA, 2015; RAHMAN; PINTO; ZANCHETTA; WALL, 2017).

Digital services can increase elderlies' safety at home. Finnish elderly often utilize digital services and applications. They have good education which is an important part of Finnish culture. Elderly citizens have an active role in the Finnish society. More and more often elderly use digital services to complete their individual service package. Cognitive capacity is important for the elderly to be able to live at home (HUOTILAINEN, 2016).

Digital services for elderly people will be the next successful story of Finland. Service providers from public, private and third sectors collaborate for creating shared infrastructure for these services. Business Finland (the most important public funding agency for research funding in Finland) has also an important role in the collaboration. Family members participation in elderly's life is important for living at home. They can support old person in using digital services. Professionals and family members collaborate when elderly use digital applications and services at home. Also, cognitive level of person influences which way the person can use different applications.

Developed countries showed a dynamic of first growing economically and then getting older, in Brazil and in other developing countries the process was the opposite. This dynamic makes the aging process very difficult due to the social and health demands arising from the accelerated increase of the elderly population in a short time. Thus with low socioeconomic status and education, health problems worsen with advancing age. In Brazil, in order to compensate for this inequality, the Unified Health System was 
created to guarantee fair access to health services. Public policies were also created to guarantee the rights of the elderly through the National Policy of the Elderly (Law Number. 8,842 / 94) and the Statute of the Elderly (Law Number. 1,0741 / 2003). In 1999 the National Health Policy for the Elderly was created through Ordinance GM / MS no. 1395/1999, revised by Ordinance GM / MS 2528/2006, which defined the promotion of successful aging, maintenance of autonomy, maintenance of independence and rehabilitation of functional capacity, assistance to health needs and development of strategies for informal care. In this sense, health care strategies for the elderly were created in primary care networks and also in home care (LOUVISON, 2014).

Face to this context of changes in the aging process one of the challenges is the maintenance of the elderly in an independent and autonomous way in their homes, avoiding early institutionalization. In order to promote this situation and made it viable, it is necessary to develop and maintain cognitive abilities, as well as to develop services that assist the elderly, such as home delivery services.

In accordance with the presented realities, the Beyond research collaboration in successful aging topic between Feevale University and Hamk University of applied sciences has started in 2015. The main research question has been find out older person's possibilities to utilize digital services in their daily life.

The aging process is also marked by cultural differences that help or hamper the experience of this phase of life. As there are different social and cultural conditions in Brazil and Finland, the objective of the present study was to evaluate and compare the cognitive performance of elderly people in communities in both countries.

The results of this study are intended to understand the application of technogerontology and assist the development of home delivery services in different cultural contexts. As there are very different social conditions in Brazil and Finland, it is interesting to understand the characteristics of the cognitive abilities of older people in these contexts to assess the specific needs for the implementation of digital services that are effective for older people in these countries. In this sense, the understanding of these capacities is important to allow the elderly to maintain their residence, with quality of life, for the longest possible time, thus promoting the successful aging.

\section{METHOD}

The study design was descriptive, quantitative and cross-sectional. The sample consisted of 197 elderly people living in Ivoti / Brazil and 93 in Riihimäki / Finland.

In Finland the sample of elderly was collected in one of the south-eastern cities. The study involved 93 elderly people whose test results were collected randomly during 2014. The people were 65-85 years 
old men and women (mostly women). All of them have used home health care services, had high-level education and live in safe social environment. They don't have depression or any other mental disease. Ethical review has been done for the Finnish research in the health care center of the sample area. The health care center gave permission for the research. All information has been processed anonymously and confidentially.

The municipality of Ivoti, Brazil, has an estimated population in 2013 of 21,460 people, an area of the territorial unit of $63,161 \mathrm{~km} 2$ and a demographic density of 314.71 inhabitants per $\mathrm{km} 2$. The municipality is within the metropolitan region of Rio Grande do Sul State, has a predominantly German ethnic identity and a high rate of human development. The total resident population of elderly over 60 in the municipality is 1959 elderly. In the range of 60 to 69 years is 1,165 people, being 517 men (421 from urban and 96 from rural) and 648 women (603 from urban and 45 from rural). The population over the age of 70 years is 794 people, comprising 314 men (284 urban and 29 rural) and 480 women (408 urban and 73 rural) (IBGE, 2013). The sample consisted of 194 elderly people between 60 and 79 years old, of both sexes. Inclusion criteria were to be older than 60 years old, living in the municipality of Ivoti, not being institutionalized or hospitalized, having mental and health conditions to have independence and autonomy to participate in the study and to sign the consent form. Exclusion criteria were presenting dementia processes, frailty syndrome, being hospitalized or institutionalized. The project was approved by the Ethics Committee of the Feevale University.

The instrument used for the study was the Mini Mental State Examination (MMSE). It is a cognitive screening test widely used in the evaluation of the elderly and was developed by Folstein, Folstein and McHugh in 1975 and translated in Brazil by Bertolucci et al. (1994). It consists of several questions typically grouped into seven categories, each designed to assess specific cognitive functions: time orientation (5 points), location orientation (5 points), three word record (3 points), attention and calculus (5 points), remembering the three words (3 points), language (8 points) and visual constructive ability ( 1 point). Its application is fast, ranging from 5 to 10 minutes. Items are rated for a score ranging from 0 to 30 points. Schooling was pointed out by Bertolucci et al. (1994), Juva et al. (1997), Almeida and Almeida (1999) as a determining factor for the evaluation, presenting different cutoff points according to the number of years of study. In clinical practice, the cutoff point 23 or 24 is the most commonly used, presenting high sensitivity and specificity for detecting cognitive impairment. The influence of the social and economic environment is also identified in the study by Kukull (1998) and Bertolucci et al. (1994). According to Almeida and Almeida (1999) MMSE scores are significantly influenced by age. 


\section{RESULTS}

Data analysis was performed to compare samples from two cities Ivoti in Brazil and Riihimäki in Finland. Table 1 shows the description of age and gender distribution in both samples. A greater presence of older women could be identified in both samples.

Table 1 - Descriptive analysis of age and sex variables

\begin{tabular}{|c|c|c|c|c|c|c|c|c|}
\hline \multirow[b]{2}{*}{ City } & & & & \multicolumn{4}{|c|}{ Age range } & \multirow[b]{2}{*}{ Total } \\
\hline & & & & \multirow{2}{*}{$\begin{array}{c}60 \text { to } 69 \\
\text { years } \\
34\end{array}$} & \multirow{2}{*}{$\begin{array}{c}70 \text { to } 79 \\
\text { years } \\
21\end{array}$} & \multirow{2}{*}{$\begin{array}{c}80 \text { to } 89 \\
\text { years } \\
0\end{array}$} & \multirow{2}{*}{$\begin{array}{c}90 \text { to } 99 \\
\text { years } \\
0\end{array}$} & \\
\hline Ivoti & Sex & Male & $N$ & & & & & 55 \\
\hline & & & $\%$ Sex & $61,8 \%$ & $38,2 \%$ & $0 \%$ & $0 \%$ & $100,0 \%$ \\
\hline & & & $\%$ Age range & $27,0 \%$ & $30,9 \%$ & $0 \%$ & $0 \%$ & $28,4 \%$ \\
\hline & & & \%otal & $17,5 \%$ & $10,8 \%$ & $0 \%$ & $0 \%$ & $28,4 \%$ \\
\hline & & Female & $N$ & 92 & 47 & 0 & 0 & 139 \\
\hline & & & $\%$ Sex & $66,2 \%$ & $33,8 \%$ & $0 \%$ & $0 \%$ & $100,0 \%$ \\
\hline & & & $\%$ Age range & $73,0 \%$ & $69,1 \%$ & $0 \%$ & $0 \%$ & $71,6 \%$ \\
\hline & & & \%otal & $47,4 \%$ & $24,2 \%$ & $0 \%$ & $0 \%$ & $71,6 \%$ \\
\hline & Total & & $N$ & 126 & 68 & 0 & 0 & 194 \\
\hline & & & $\%$ Sex & $64,9 \%$ & $35,1 \%$ & $0 \%$ & $0 \%$ & $100,0 \%$ \\
\hline & & & \% Age range & $100,0 \%$ & $100,0 \%$ & $0 \%$ & $0 \%$ & $100,0 \%$ \\
\hline & & & Total & $64,9 \%$ & $35,1 \%$ & $0 \%$ & $0 \%$ & $100,0 \%$ \\
\hline \multirow[t]{12}{*}{ Riihimäki } & \multirow[t]{8}{*}{ Sex } & \multirow[t]{4}{*}{ Male } & $N$ & 0 & 8 & 19 & 0 & 27 \\
\hline & & & $\%$ Sex & $0 \%$ & $29,6 \%$ & $70,4 \%$ & $0,0 \%$ & $100,0 \%$ \\
\hline & & & $\%$ Age range & $0 \%$ & $32,0 \%$ & $35,8 \%$ & $0,0 \%$ & $29,0 \%$ \\
\hline & & & \% Total & $0 \%$ & $8,6 \%$ & $20,4 \%$ & $0,0 \%$ & $29,0 \%$ \\
\hline & & \multirow[t]{4}{*}{ Female } & $N$ & 4 & 17 & 34 & 11 & 66 \\
\hline & & & $\%$ Sex & $6,1 \%$ & $25,8 \%$ & $51,5 \%$ & $16,7 \%$ & $100,0 \%$ \\
\hline & & & $\%$ Age range & $100,0 \%$ & $68,0 \%$ & $64,2 \%$ & $100,0 \%$ & $71,0 \%$ \\
\hline & & & \% Total & $4,3 \%$ & $18,3 \%$ & $36,6 \%$ & $11,8 \%$ & $71, \%$ \\
\hline & \multirow{4}{*}{\multicolumn{2}{|c|}{ Total }} & $N$ & 4 & 25 & 53 & 11 & 93 \\
\hline & & & $\%$ Sex & $4,3 \%$ & $26,9 \%$ & $57,0 \%$ & $11,8 \%$ & $100,0 \%$ \\
\hline & & & $\%$ Age range & $100,0 \%$ & $100,0 \%$ & $100,0 \%$ & $100,0 \%$ & $100,0 \%$ \\
\hline & & & \% Total & $4,3 \%$ & $26,9 \%$ & $57,0 \%$ & $11,8 \%$ & $100,0 \%$ \\
\hline
\end{tabular}

Source: Database Ivoti/Riihimäki 
Table 2 presents the descriptive MMSE results presented by the sample of elderly from Ivoti and Riihimäki. The results showed an average of 67, 55 years, with predominance of women, and regarding to the level of education it is observed that the majority $75.9 \%$ have incomplete elementary school. The best performances in the Ivoti sample occurred in temporal orientation, spatial orientation, immediate memory, language constructive vision ability. In the Riihimäki sample the average age was 82 years and the best performance was in spatial orientation and immediate memory.

Table 2 -Descriptive analysis of MMSE

\begin{tabular}{|c|c|c|c|c|c|c|c|c|c|c|c|}
\hline \multicolumn{3}{|c|}{ City } & ఊ్ర & 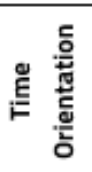 & 恶 & 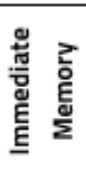 & 总 & 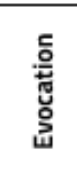 & 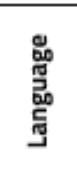 & 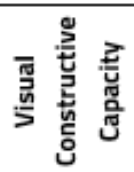 & 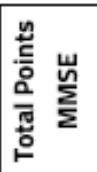 \\
\hline \multirow{6}{*}{ 究 } & \multirow[t]{2}{*}{$N$} & Valid & 194 & 194 & 194 & 194 & 194 & 194 & 194 & 194 & 194 \\
\hline & & Missing & 0 & 0 & 0 & 0 & 0 & 0 & 0 & 0 & 0 \\
\hline & \multicolumn{2}{|c|}{ Mean } & 67,55 & 4,69 & 4,82 & 2,94 & 2,91 & 0,80 & 7,33 & 0,81 & 24,24 \\
\hline & \multicolumn{2}{|c|}{$\begin{array}{l}\text { Std. } \\
\text { Deviation }\end{array}$} & 5,629 & 0,739 & 0,539 & 0,262 & 1,777 & 1,049 & 1,140 & 0,390 & 3,612 \\
\hline & \multicolumn{2}{|c|}{ Minimum } & 60 & 0 & 2 & 1 & 0 & 0 & 2 & 0 & 11 \\
\hline & \multicolumn{2}{|c|}{ Maximum } & 79 & 5 & 5 & 3 & 5 & 3 & 8 & 1 & 30 \\
\hline \multirow{6}{*}{ 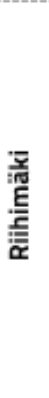 } & \multirow[t]{2}{*}{$N$} & Valid & 93 & 93 & 93 & 93 & 93 & 93 & 93 & 93 & 93 \\
\hline & & Missing & 0 & 0 & 0 & 0 & 0 & 0 & 0 & 0 & 0 \\
\hline & \multicolumn{2}{|c|}{ Mean } & 82,06 & 3,16 & 4,49 & 2,82 & 2,14 & 0,73 & 6,39 & 0,51 & 20,45 \\
\hline & \multicolumn{2}{|c|}{$\begin{array}{l}\text { Std. } \\
\text { Deviation }\end{array}$} & 6,575 & 1,610 & 0,916 & 0,570 & 1,880 & 1,002 & 1,701 & 0,503 & 5,036 \\
\hline & \multicolumn{2}{|c|}{ Minimum } & 62 & 0 & 1 & 1 & 0 & 0 & 0 & 0 & 6 \\
\hline & \multicolumn{2}{|c|}{ Maximum } & 93 & 5 & 5 & 3 & 5 & 3 & 8 & 1 & 29 \\
\hline
\end{tabular}

Source: Database Ivoti/Riihimäki

Table 3 presents the MMSE results divided by age group in each city. We can observe that even in this way the best results are in Ivoti. In the age group of 70 to 79 years this difference is clearer due to the sample size. 
Table 3 -Descriptive analysis of MMSE by age group

\begin{tabular}{|c|c|c|c|c|c|c|c|c|c|c|}
\hline Z & 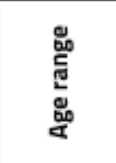 & & 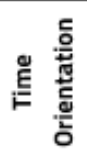 & 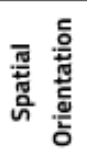 & 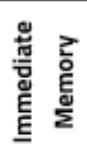 & 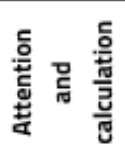 & 을 & 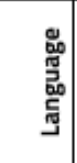 & 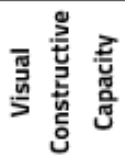 & 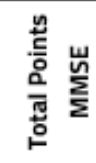 \\
\hline \multirow{4}{*}{ 퐁 } & \multirow{2}{*}{$\begin{array}{l}60 \text { to } 69 \\
\text { years }\end{array}$} & $N$ & 126 & 126 & 126 & 126 & 126 & 126 & 126 & 126 \\
\hline & & Mean & 4,74 & 4,87 & 2,95 & 2,91 & 0,84 & 7,51 & 87 & 24,67 \\
\hline & \multirow{2}{*}{$\begin{array}{l}70 \text { to } 79 \\
\text { years }\end{array}$} & $N$ & 68 & 68 & 68 & 68 & 68 & 68 & 68 & 68 \\
\hline & & Mean & 4,60 & 4,75 & 2,91 & 2,91 & 0,74 & 7,00 & 0,71 & 23,46 \\
\hline \multirow{8}{*}{ 䆓 } & \multirow{2}{*}{$\begin{array}{l}60 \text { to } 69 \\
\text { years }\end{array}$} & $N$ & 4 & 4 & 4 & 4 & 4 & 4 & 4 & 4 \\
\hline & & Mean & 3,25 & 3,75 & 3,00 & 2,50 & 1,00 & 5,50 & 0,50 & 19,75 \\
\hline & \multirow{2}{*}{$\begin{array}{l}70 \text { to } 79 \\
\text { years }\end{array}$} & $N$ & 25 & 25 & 25 & 25 & 25 & 25 & 25 & 25 \\
\hline & & Mean & 2,80 & 4,52 & 2,88 & 1,88 & 0,80 & 6,64 & 0,52 & 20,20 \\
\hline & \multirow{2}{*}{$\begin{array}{l}80 \text { to } 89 \\
\text { years }\end{array}$} & $N$ & 53 & 53 & 53 & 53 & 53 & 53 & 53 & 53 \\
\hline & & Mean & 3,32 & 4,47 & 2,77 & 2,28 & .72 & 6,40 &, 51 & 20,70 \\
\hline & \multirow{2}{*}{$\begin{array}{l}90 \text { to } 99 \\
\text { years }\end{array}$} & $N$ & 11 & 11 & 11 & 11 & 11 & 11 & 11 & 11 \\
\hline & & Mean & 3,18 & 4,82 & 2,82 & 1,91 & .55 & 6,09 & 45 & 20,09 \\
\hline
\end{tabular}

Source: Database Ivoti/Riihimäki

To compare the means of the Mini Mental State Examination (MMSE) results, the Mann Whitney nonparametric test with acceptance level $\leq 0.05$ was used. Table 4 shows the comparison of the average results of the elderly of Ivoti and Riihimäki. The results showed that there is a significant difference in temporal orientation, spatial orientation, attention and calculation, language, visual constructive capacity and total MMSE score between the two groups, with better cognitive performance results in the Brazilian city of Ivoti. 
Table 4 - Comparison of MMSE means between the elderly of Ivoti and Riihimäki

\begin{tabular}{|l|c|c|c|c|c|c|c|c|}
\hline & $\begin{array}{c}\text { Time } \\
\text { orientatio } \\
\mathbf{n}\end{array}$ & $\begin{array}{c}\text { Spatial } \\
\text { orientatio } \\
\mathbf{n}\end{array}$ & $\begin{array}{c}\text { Immediate } \\
\text { memory }\end{array}$ & $\begin{array}{c}\text { Attention } \\
\text { and } \\
\text { calculation }\end{array}$ & Evocation & Language & $\begin{array}{c}\text { Visual } \\
\text { constructive } \\
\text { capacity }\end{array}$ & $\begin{array}{c}\text { Total } \\
\text { Points } \\
\text { MMSE }\end{array}$ \\
\hline Mann- & 3588,500 & 7365,000 & 8620,000 & 6921,000 & 8695,000 & 5406,000 & 6233,000 & 4753,0 \\
Whitney U & & & & & & & & \\
\hline Wilcoxon W & 7959,500 & 11736,000 & 12991,000 & 11292,000 & 13066,000 & 9777,000 & 10604,000 & 9124,0 \\
\hline Z & $-9,522$ & $-3,754$ & $-1,381$ & $-3,245$ &,- 555 & $-5,962$ & $-5,415$ & $-6,510$ \\
\hline $\begin{array}{l}\text { Asymp. Sig. } \\
\text { (2-tailed) }\end{array}$ & 0,000 & 0,000 & 0,167 & 0,001 & 0,579 & 0,000 & 0,000 & 0,000 \\
\hline
\end{tabular}

Source: Database Ivoti/Riihimäki

Table 5 presents the comparison analysis of MMSE results of men and women in both cities. We can identify that men sample is much smaller than the women sample, but it can be showed that, between men of the two cities, there is a significant difference between temporal orientation, spatial orientation, attention and calculation, language, constructive visual ability and MMSE total points. In the group of elderly women we identified significant differences between the group of Ivoti and Hihhimäki in the same items. 
Table 5 - Comparison of MMSE means of gender between Ivoti and Riihimäki elderly

\begin{tabular}{|c|c|c|c|c|c|c|c|c|c|}
\hline \multicolumn{2}{|c|}{ Sex } & $\begin{array}{c}\text { Time } \\
\text { orientatio } \\
\mathbf{n}\end{array}$ & $\begin{array}{c}\text { Spatial } \\
\text { orientatio } \\
\mathbf{n}\end{array}$ & $\begin{array}{c}\text { Immediate } \\
\text { memory }\end{array}$ & $\begin{array}{c}\text { Attention } \\
\text { and } \\
\text { calculation }\end{array}$ & Evocation & Language & $\begin{array}{c}\text { Visual } \\
\text { constructive } \\
\text { capacity }\end{array}$ & $\begin{array}{l}\text { Total } \\
\text { Points } \\
\text { MMSE }\end{array}$ \\
\hline \multirow{4}{*}{$\frac{0}{\frac{\pi}{n}}$} & $\begin{array}{l}\text { Mann- } \\
\text { Whitney U }\end{array}$ & 286,000 & 578,000 & 740,500 & 466,000 & 668,500 & 462,000 & 520,000 & 321,50 \\
\hline & $\begin{array}{l}\text { Wilcoxon } \\
\text { W }\end{array}$ & 664,000 & 956,000 & 1118,500 & 844,000 & 2208,500 & 840,000 & 898,000 & 699,50 \\
\hline & $z$ & $-4,967$ & $-2,414$ & $-0,044$ & $-2,810$ &,- 849 & $-2,956$ & $-2,821$ & $-4,180$ \\
\hline & $\begin{array}{l}\text { Asymp. } \\
\text { Sig(2- } \\
\text { tailed) }\end{array}$ & 0,000 & 0,016 & 0,965 & 0,005 & 0,396 & 0,003 & 0,005 & 0,000 \\
\hline \multirow{4}{*}{$\begin{array}{l} \\
\stackrel{0}{\mathrm{~d}} \\
\stackrel{\mathrm{d}}{4}\end{array}$} & $\begin{array}{l}\text { Mann- } \\
\text { Whitney U }\end{array}$ & 1861,000 & 3814,000 & 4307,000 & 3699,000 & 4139,500 & 2761,000 & 3151,500 & 2519,5 \\
\hline & $\begin{array}{l}\text { Wilcoxon } \\
W\end{array}$ & 4072,000 & 6025,000 & 6518,000 & 5910,000 & 6350,500 & 4972,000 & 5362,500 & 4730,5 \\
\hline & $z$ & $-8,144$ & $-2,910$ & $-1,614$ & $-2,275$ & $-1,249$ & $-5,065$ & $-4,613$ & $-5,227$ \\
\hline & $\begin{array}{l}\text { Asymp. } \\
\text { Sig(2- } \\
\text { tailed) }\end{array}$ & 0,000 & 0,004 & 0,107 & 0,023 & 0,212 & 0,000 & 0,000 & 0,000 \\
\hline
\end{tabular}

\section{Source: Database Ivoti/Riihimäki}

Table 6 shows the analysis of the comparison of means between the elderly of Ivoti and Riihimäki regarding to the variable age groups. In the first age group there are few elderly people in Riihimäki, but nonetheless, we identified a significant difference in temporal orientation, spatial orientation and visual constructive capacity. In the second age group from 70 to 79 years old, we have the most significant results depending on the sample size. We identified in the age group of 70 years a significant difference in temporal orientation, attention and calculation, visual constructive capacity and total MMSE score. 
Table 6 - Comparison of the MMSE means of the age group variable between the elderly of Ivoti and Riihimäki

\begin{tabular}{|c|c|c|c|c|c|c|c|c|c|}
\hline & ge range & $\begin{array}{c}\text { Time } \\
\text { orientatio } \\
\mathbf{n} \\
\end{array}$ & $\begin{array}{c}\text { Spatial } \\
\text { orientatio } \\
\mathbf{n} \\
\end{array}$ & $\begin{array}{c}\text { Immediate } \\
\text { memory }\end{array}$ & $\begin{array}{c}\text { Attention } \\
\text { and } \\
\text { calculation }\end{array}$ & Evocation & Language & $\begin{array}{c}\text { Visual } \\
\text { constructive } \\
\text { capacity }\end{array}$ & $\begin{array}{l}\text { Total } \\
\text { Points } \\
\text { MMSE }\end{array}$ \\
\hline & $\begin{array}{l}\text { Mann- } \\
\text { Whitney U }\end{array}$ & 151,500 & 145,500 & 240,000 & 232,000 & 232,000 & 167,000 & 158,000 & 239,00 \\
\hline 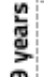 & $\begin{array}{l}\text { Wilcoxon } \\
W\end{array}$ & 161,500 & 155,500 & 8241,000 & 242,000 & 8233,000 & 177,000 & 168,000 & 249,00 \\
\hline $\begin{array}{l}0 \\
0 \\
\end{array}$ & $z$ & $-2,116$ & $-2,670$ & $-0,445$ & $-0,275$ & $-0,298$ & $-1,398$ & $-2,118$ & $-0,176$ \\
\hline 8 & $\begin{array}{l}\text { Asymp. } \\
\text { Sig(2- } \\
\text { tailed) }\end{array}$ & 0,034 & 0,008 & 0,656 & 0,783 & 0,766 & 0,162 & 0,034 & 0,860 \\
\hline & $\begin{array}{l}\text { Mann- } \\
\text { Whitney U }\end{array}$ & 316,000 & 785,500 & 843,000 & 585,000 & 839,000 & 664,500 & 692,000 & 510,50 \\
\hline 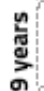 & $\begin{array}{l}\text { Wilcoxon } \\
W\end{array}$ & 641,000 & 1110,500 & 1168,000 & 910,000 & 3185,000 & 989,500 & 1017,000 & 835,50 \\
\hline \& & $z$ & $-5,185$ & $-0,812$ & $-0,133$ & $-2,337$ & $-0,108$ & $-1,710$ & $-1,664$ & $-2,952$ \\
\hline 운 & $\begin{array}{l}\text { Asymp. } \\
\text { Sig(2- } \\
\text { tailed) }\end{array}$ & 0,000 & 0,417 & 0,894 & 0,019 & 0,914 & 0,087 & 0,096 & 0,003 \\
\hline
\end{tabular}

Source: Database Ivoti/Riihimäki

\section{DISCUSSION}

Health and social services have important role in supporting elderlies ${ }^{\prime}$ active aging. In Finland health services have focused on supporting independent living and active aging. Health care systems are different in Finland and in Brazil, both systems have a goal in home living, development of primary health care, and elderlies active living and coping at home. Both countries are developing services for this purpose.

Older people's attitudes towards living at home are mainly positive. Home care service delivery must have purpose, goals and high-quality implementation. Then it supports elderly person's independent and safe living at home as long as possible.

Social interaction and community are important for the maintenance of older people's cognitive abilities. Using electronic games often requires a certain cognitive level of people if he or she is actively involved in the use of services. Community spirit and the sense of belonging to the group increases and also supports the opportunities of older people to use different and new services (CHAPMAN; KEATING; EALES, 2003).

However, for older people to make use of these services and to implement or improve gerontechnology strategies, it is important to know the skills that are preserved in older people, those that need to be 
stimulated, as well as to understand the cultural context in which they live. The results of our study showed that there are no significant differences in cognitive performance of men and women in Ivoti and Riihimäki, despite the small number of men in both samples. But despite the feminization of old age, it is known that men have greater difficulty and willingness to participate in research than women.

In the comparison between the cities, it was observed that, despite the economic and educational differences, the Brazilian municipality presented better results. Obviously, the factor age interferes with cognitive performance, however, when compared to the same age group of 70 years, significant differences were also identified, including the total MMSE score.

The data allow us to understand that separately Ivoti's group of older people need to develop more cognitive performance in the areas of attention, calculation and evocation. Inhibition disorder theory refers to the difficulty of older people to focus attention on a subject and to inhibit irrelevant information. In the aging process the use of some resources that could help in attention are more restricted. In this sense, divided attention is one of the components of working memory that helps older people to use digital tools and applications. It must be remarked that these actions are new tasks for people who are in old age today. Probably, the new generations, when they get older, will not have the same difficulties since they have been acquainted to the digital world since childhood. As there are many skills to be registered when using a new digital tool or application, the elderly get lost in the record of the steps by the excess of information that needs to be assimilated, failing to discern the most relevant, or even the order of execution (PARENTE; WAGNER, 2006).

Riihimäki's group of older people had more difficulties and would need to further develop cognitive performance in the areas of temporal orientation, attention and calculation, evocation, language, and visual constructive ability. The difficulty in language also refers to the fact that attention, in the sense of changing or jumping between various subjects, without actually being able to focus attention (PARENTE; WAGNER, 2006).

The most significant differences we found between the Ivoti and Riihimäki groups of older people were in temporal orientation, attention and calculation, constructive visual ability and total MMSE score. In this sense, we can identify that several aspects throughout the history of these cultural groups may have interfered in this result, requiring studies that evaluate more variables than only cognitive performance. But it can be inferred that these groups that have the same age show, during their old age, different situations in various aspects. Ivoti's Brazilian group did not have as much access to formal education as it does not have as favorable socio-economic structure as the Finnish group of Riihimäki. However, the Brazilian group has independence and autonomy which enables a good family and social relationship. 
Thus, the Brazilian group has the possibility of intergenerational relationship and seeks coexistence in different groups with activities of living, sports, dance, manual skills, etc. The community itself, when it realizes that an elderly person has integration problems, helps in the search for social activities. It is noteworthy that many of the elderly also maintain work activities to supplement their income, as well as assisting their children in the care of grandchildren and great-grandchildren.

The study by Watfa et al. (2011) demonstrated as significant predictors of annual changes in MMSE in a multiple regression model education level and difficulty in social relations. According to Menard (2002), social relationships, especially through the family, are an important support for the mental health of the elderly. For the author, the relationship between health, disease, aging and social relations is a reciprocal relationship.

Muscari et al. (2018) also report that prolonged step test was the main predictor of both crosssectional cognitive deficit and longitudinal cognitive decline. Continuous aerobic training can prevent or reduce the speed of cognitive impairment. The elderly people of Ivoti are very active, both for the walks they perform on a daily basis, as well as for the physical and dance activities that they develop from the activities offered by the city hall and gyms.

It is noteworthy that in the successful aging process there is a balance between losses and gains, consequently in the area of cognitive performance, some skills and strategies are lost or no longer work as before, but others can be acquired. Thus, it is up to technology developers for the elderly to understand cognitive processes and to make clear in their devices that allow less attention dispersion, as well as less distractors (lights or keys) and shorter paths to reach the goal. Relevant written information indicating the tasks and steps to follow is also relevant. The conditioning of an action can take many days or attempts, being important the emotional reinforcement and the gamefication.

\section{CONCLUSION}

In Brazil, a more social and communicative lifestyle and a more connective relationship between family members can influence the cognitive ability of the elderly. The elderly in Brazil enjoy more time outdoors and perform different activities that cognitively and socially stimulate the improvement of quality of life. The elderly in the study have a community that values their social role, an action of the municipality to promote activities aimed at the elderly in terms of recreation and physical activities. In addition, older people are encouraged to live independently in their homes and with quality of life, surrounded by family and friends. Family lifestyle and role are significant for cognitive ability. In Finland, the elderly live alone at home and the municipalities are responsible for providing and producing services for the elderly. These 
services are performed by trained professionals. By changing society and the service system in Finland, the role of the elderly family is growing. The importance of cooperation between professionals, partners and volunteers is increasing. A common lifestyle complemented by up-to-date electronic services will enable seniors to lead a quality and lasting life at home.

\section{REFERENCES}

ALMEIDA, O. P.; ALMEIDA, S. A. Short versions of the Geriatric Depression Scale: A study of their validity for the diagnosis of major depressive episode according to ICD-10 and DSM-IV. Int J Geriatr Psychiatry, v. 14, n. 10, p. 858-65, 1999.

BERTOLUCCI, P. H.; BRUCKI, S. M.; CAMPACCI, S. R. et al. The mini-mental state examination in a general population: impact of educational status. Arq. Neuropsiquiatra, v. 52, n. 1, p. 1-7, mar. 1994.

BIRREN, J. E.; BIRREN, B. A. The concepts, models, and history of the psychology of aging. In: BIRREN, J. E.; SCHAIE, K. W. (Eds.), Handbook of the psychology of aging, San Diego: Academic Press, 1990. p. $3-20$.

BOECKXESTAENS, P.; GRAAF, P. Primary care and care for the old persons: Position paper of the European forum for primary care. Quality in primary care, v. 19, p. 369-389, 2011.

CHAPMAN, S. A.; KEATING, N.; EALES J. Client-centered, community based care for frail seniors. Health and social care in the community, v. 11, n. 3, p. 253-261. 2003.

\section{COMISSÃO EUROPEIA. Livro branco sobre o futuro da Europa: reflexões e cenários para a EU-27 em}

2025. Bruxelas: Comissão Européia, 2017.

FOLSTEIN, M. F.; FOLSTEIN, S. E.; MCHUGH, P. R. "Mini-mental state": A practical method for gradind the cognitive state of patients for the clinician. Journal of Psychiatric Research, v. 12, n.3, p. 189-198, nov. 1975.

HAYFLICK, L. Entropy explains aging, genetic determinism explains longevity, and undefined terminology explains misunderstanding both. PLoS Genet., v. 3, n. 12, p. e220, dez. 2007.

HUOTILAINEN, M. Are there elderly people of the future? Helsinki: University of Helsinki, Cognitive Brain Research Unit, 2016. Disponivel em: <www.finlandhealth.fi/-/>. Acesso em: 27 jul 2019. 
IBGE. Censo demográfico 2010. Brasília: IBGE, 2013. Disponível em: <http://cidades.ibge.gov.br/xtras/ perfil.php?lang=codmun=431080 >. Acesso em: 06 nov. 2018.

JUVA, K.; MÄKELÄ, M.; ERKINJUNTTI, T.; SOLKAVA, R.; YLIKOSKI, R.; VALVANNE, J.; TILVIS, R. Functional assessment scales in detecting dementia. Age Ageing, v. 26, n. 5, p. 393-400, 1997.

KEHUSMAA, S.; VAINIO, S.; ALASTALO, H. Ikääntyneet palvelun käyttäjät tuntevat olonsa turvalliseksi mutta hoidon suunnitteluun osallistumisessa on kehitettävää. Tutkimuksesta tiiviisti 13. Terveyden ja Hyvinvoinnin Laitos, 2016.

KUKULL, W. A. Problems in measuring and interpreting cognitive decline. J. Am. Geriatr. Soc., v. 46, n. 12, p. 1578-1579, 1998.

LOUVISON, M. C. P. Políticas públicas e envelhecimento. In: MENDES, T. A. B. Geriatria e gerontologia. Barueri: Manole, 2014. p. 91-107.

MENARD, S. Apoio social e saúde entre idosos. Sociologias, Porto Alegre, v. 4, n. 7, p. 156-175, jan/jun 2002.

MORAGAS, R. M. Gerontologia social: Envelhecimento e qualidade de vida. São Paulo: Editora Paulinas, 2010.

MUSCARI, A.; SPILLERA, I.; IANCHIA, G.; FABBRIA, E.; FORTIA, P.; MAGALOTTIB, D.; PANDOLFIC, P.; ZOLI , M. Predictors of cognitive impairment assessed by Mini Mental State Examination in communitydwelling older adults: relevance of the step test. Experimental Gerontology, v. 108, p. 69-76, 2018.

PARENTE, M. A. M.; WAGNER, G. P. Teorias abrangentes sobre envelhecimento cognitivo. In: PARENTES, M. A. M (Org. ). Cognição e envelhecimento. Porto Alegre: Artmed, 2006. p. 31- 46.

RAHMAN, R.; PINTO, R.; ZANCHETTA, M.; WALL, M. Delivery of community-Based Care Through Inter-professional Teams in Brazil's Unified Health System (UHS): Comparing Perceptions based on a comparison between the Finnish and Brazilian elderly MMSE test results Across Community Health Agents (CHAs). Nurses and Physicians, v. 42, p. 1187-1196, 2017.

ROBINE, J. Successful aging and the longevity revolution. FERNÁNDEZ-BALLESTEROS, R.; BENETOS, A., ROBINE, J. (Eds.). The Cambridge Handbook of Successful Aging. United Kingdom: Cambridge University Press, 2019. p. 1-9. 


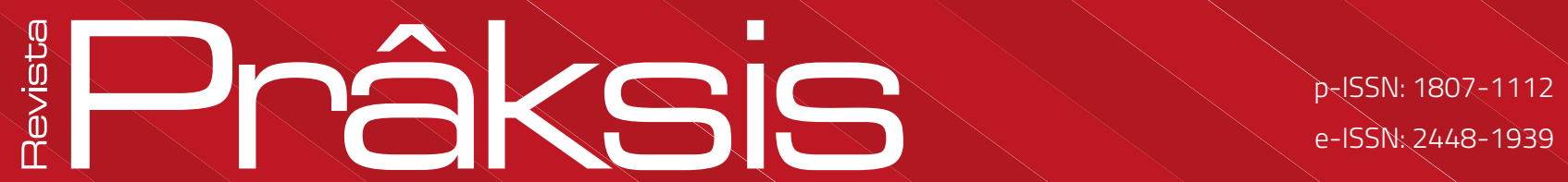

THUME, E.; FACCHINI, L.; WYSHAK, G.; CAMPBELL, P. The utilitation of home care by the elderly in Brazil’s Primary Health Care System. American Journal pf Public Health, v. 101, n. 5, 2011.

TURJAMAA, R. Is it time to comprehensive approach in older home care planning in Finland? Scandinavian Journal of Caring Sciences, v. 29, p. 317-324, 2015.

WATFA, G.; HUSSON, N.; BUATOIS, S.; LAURAIN, M.C.; MIGET, P.; BENETOS, A. Study of Mini-Mental State Exam evolution in community dwelling subjects a aged over 60 years without dementia. The Journal of Nutrition, Health \& Aging, v. 15, n. 10, p. 901-904, 201. 